\title{
The Frequency of Meningitis Cases in Zagazig Fever Hospital: A Cross-sectional Study
}

\author{
Hosam M Dawod ${ }^{1}$, Ahmed M Naguib ${ }^{2}$, Samar A Amer \\ and Lamiaa A Mohamed ${ }^{4}$ \\ ${ }^{1}$ Tropical Medicine Department, Faculty of Medicine, Zagazig University, Egypt. \\ ${ }^{2}$ Zagazig Fever Hospital, Egypt. \\ ${ }^{3}$ Public Health and Community Medicine Department, Faculty of Medicine, Zagazig University. \\ ${ }^{4}$ Clinical Pathology Department, Faculty of Medicine, Zagazig University,Egypt.
}

Corresponding Author

Hosam Mohamed

Dawod

Mobile:

00966544635448

00201113008201

\section{E mail:}

hosamgastro@yahoo.c om

Key words: Meningitis, Zagazig Fever Hospital, Neisseria meningitides
Background and study aim: Meningitis is the inflammation of meninges and can be life-threatening in some cases. The study aimed to determine the frequency and clinical presentations of the meningitis cases in Zagazig Fever Hospital to put recommendations to assist in improving the preventive and management measurements for meningitis.

Patients and Methods: A cross-section study included all of 70 meningitis patients in Zagazig Fever Hospital, who fulfilled the selection criteria, over a period of one year from September 2016 to September 2017. The data collection sheet included demographic, clinical assessments, diagnostic lumbar puncture with CSF analysis.

Results: The majority of meningitis cases were males $(57.1 \%)$, from urban areas $(67.1 \%)$, aged less than ten years or more

\section{INTRODUCTION}

Meningitis is inflammation of the protective membranes covering the brain and spinal cord and can be lifethreatening condition in some cases [1]. Meningitis is an endemic disease in Egypt [2]. It is prevalent in developing countries, due to low socioeconomic conditions, with endemicity rate of $1.5 / 100,000$ and 20/100,000 population in the developed and developing countries, respectively [3,4]. Worldwide, 1 million cases are observed yearly out of which; 170000 are life-threatening [5]. Ten percent of survivors have disabled neurologic sequelae or other complication [6].

Prevention, prompt diagnosis, and appropriate treatment of meningitis are mandatory for good outcome and than forty years, and diagnosed in winter (42.9\%), especially in February. According to the CSF culture results, patients were classified into two groups; $87.1 \%$ as aseptic meningitis (group A) and $12.8 \%$ as bacterial meningitis (group B). Neisseria meningitides was the common cause of bacterial meningitis. The death rate was $(11.4 \%)$, and the old age was a significant risk factor for mortality $(\mathrm{P}=0.02)$.

Conclusion: Meningitis is a real health problem in Al Sharkia Governorate; Neisseria meningitides was the common cause of septic meningitis. Health authorities in Al Sharkia governorate should focus their preventive efforts on the age group < 10 years and $>40$ years.

to reduce mortality and long-term morbidity [7]. The main three diagnostic symptoms include neck stiffness, acute onset of high fever and mental status change or a headache, although these manifestations account for about $45 \%$ of the cases of bacterial meningitis [8]. The examination of cerebrospinal fluid (CSF) is the cornerstone of diagnosis for suspected meningitis cases and overestimated risk for cerebral herniation should not delay the lumbar puncture [9].

Worldwide, bacterial meningitis is mainly due to Streptococcus pneumonia, Neisseria meningitidis, and Haemophilus influenza type $b$, however, over the last decades, changes in the distribution of the causative agents and the affected age groups have been noticed in different areas, due to the implementation of

Dawod et al., Afro-Egypt J Infect Endem Dis 2019; 5(2):158-166

https://aeji.journals.ekb.eg/

http://mis.zu.edu.eg/ajied/home.aspx 
immunization programs with polysaccharide vaccines [10]. Its incidence declined by $31 \%$ between the year 1998 and 2007 with the availability of immunizations for Neisseria meningitides and Streptococcus pneumonia, but there are still at least 4,000 cases a year, including about 500 that are fata [11]. The incidence and case-fatality rates for bacterial meningitis vary by region, country, pathogen, and age group and without treatment, the fatality rate can be $70 \%$, and 1 in 5 survivors may have permanent sequelae [12]. Bacterial meningitis is diagnosed mainly by positive CSF culture, but the antimicrobial intake before the culture can lead to a negative result [1].

Recently in Egypt, the main cause of bacterial meningitis was pneumococcal meningitis, which reflects epidemiological changes in the disease $[13,14]$, because Neisseria meningitides was the common cause for a long time [15]. The initial antibiotic treatment of acute bacterial meningitis is usually empiric while studying the epidemiology of bacterial meningitis in a certain community can lead to the best therapeutic option $[\mathbf{1 6 , 1 7 ]}$. Aseptic meningitis refers to meningitis cases with a negative CSF bacterial culture and usually caused by viruses [18]. It is a mild illness and needs no treatment but in some cases can be lifethreatening. Pyrexia and headache are more common in aseptic meningitis than in bacterial meningitis cases [19].

Zagazig is the capital city of Al Sharqia Governorate, the $3^{\text {rd }}$ most populous governorates in Egypt and with poverty rates more than $60 \%$ [20], and served by Zagazig Fever Hospital (ZFH). Therefore, this study aimed to determine the frequency and clinical presentations of the meningitis cases in ZFH (2016-2017) to put recommendations to assist in improving the preventive and management measurements for meningitis.

\section{PATIENTS AND METHODS}

A cross-section study during a period of one year from September 2016 to September 2017 included 70 meningitis patients in ZFH. Inclusion criteria: Patients with the clinical picture and CSF analysis suggestive of meningitis. Exclusion criteria: any case with clinical picture suggestive of cerebrovascular disease, brain tumors or other neurological insults and other causes of fever or coma.
The data collection tool: a well-structured data sheet; that composed mainly from five parts;

1. The sociodemographic data: age, sex, and residence, seasonal distribution of cases

2. Clinical assessments: we assessed fever, headache, neck rigidity, disturbed consciousness level, convulsions, projectile vomiting, coma, presence of rash, focal neurological signs, history of antibiotic use, history of chronic disease, past history of head trauma and history of previous similar attacks. Examination for meningeal irritation signs as Neck rigidity Kernig's sign (flexing the patient's hip 90 degrees then extending the patient's knee causes pain) and Brudzinski's sign (Flexing the patient's neck causes flexion of the patient's hips and knee). Examination of the motor system, sensory system, and cranial nerves.

3. Laboratory tests: included complete blood picture, random blood sugar, C-reactive protein (CRP was considered positive if $>6.0 \mathrm{mg} / \mathrm{L}$ and negative if $<6.0 \mathrm{mg} / \mathrm{L}$ ), serum electrolytes, liver function tests, and kidney function tests.

4. A diagnostic lumbar puncture (LP) with CSF sampling: Done on the first day of admission on an urgent base (within 2 hours) under local anesthesia by putting the patient on his side then inserting a needle into the dural sac to collect the CSF. The CSF samples, after excluding the blood contaminated ones were divided into two parts, one part was used in routine examinations, and the other part was stored at $-70^{\circ} \mathrm{C}$ for our study. CSF was examined for the opening pressure, gross appearance, and then distributed into four tubes as follows: Tube 1. For glucose and protein levels, Tube 2. For cell count with the differential count (Tube 3). For Gram stain, bacterial cultures (chocolate agar, blood agar, MacConkey agars, and India ink preparation when cryptococcal meningitis was clinically suspected), acid-fast bacillus (AFB) stain and tuberculosis culture, Tube 4. Hold for a repeat cell count with the differential count, if needed or for other needed tests. A concern regarding LP is that herniation can sometimes occur in meningitis as the consequence of severe cerebral edema or acute hydrocephalus or possible mass lesion. However, a screening head computerized tomography (CT) is not necessary for the majority of patients $[\mathbf{2 1 , 2 2 ]}$. Patients with 
clinical risk factors for raised intracerebral pressure with subsequent risk for cerebral herniation (a new-onset seizure within one week of presentation, papilledema, abnormal level of consciousness, or focal neurologic deficit) had a CT scan of the head prior to LP based upon the 2004 Infectious Diseases Society of America (IDSA) guidelines for the management of meningitis [16,23]. Empiric treatment was initiated as quickly as possible after the performance of the lumbar puncture (LP) or when it was deferred with the following regimen: Vancomycin plus a third-generation cephalosporin (ceftriaxone or cefotaxime) plus ampicillin (in adults $>50$ years of age or children $<3$ months) plus dexamethasone (starting before the first dose of antibiotics) [16].

\section{Ethical considerations:}

A review board of Tropical Medicine Department of Zagazig University approved the protocol in concordance with the Medical Association Code of Ethics (declaration of Helsinki). The data were collected after written informed consent from all participants.

\section{Statistical Analysis :}

All the data were analyzed using SPSS 20.0 for Windows (SPSS Inc., Chicago, IL, USA) \& MedCalc 13 for windows (Med Calc Software, Ostend, Belgium). Continuous quantitative variables e.g., age were summarized using expressed as mean, median, slandered deviation (SD) and range and qualitative data categorical qualitative variables; were expressed as absolute frequencies (number) and relative frequencies (percentage). Independent samples Student's t-test was used to compare two groups of normally distributed data while the Mann-Whitney U test was used for non-normally distributed data. Categorical results were compared by Chi-square test once applicable. Correlation between variables was done using correlation coefficient (r). Odds Ratio was used for evaluating the probability of various variables in predicting mortality in a case of meningitis for all above-mentioned Statistical tests done, the threshold of significance is fixed at 5\%level (pvalue). A $p$ value of $<0.05$ indicates a significant result.

\section{RESULTS}

This study included a total of 70 meningitisdiagnosed cases in one year in ZFH with a median age of 26.5 years (mean age of $28 \pm 21.5$ ). Most of the cases were admitted in the winter
(42.9\%), especially February, and from the urban areas $(67.1 \%)$ (Table. 1). As illustrated in figure 1 , all cases were feverish then altered mental status, neck rigidity and headache in descending orders. Moreover, the signs of meningeal irritation were present in $45.6 \%$ of cases either separately or collectively. Most cases (82.9\%) came to the hospital with a history of antibiotic use (partially treated meningitis), that may have interfered with the results of CSF culture making it sterile. In 16 patients (22.9\%), at least one chronic illness was present; diabetes in 7 patients, (10\%) hypertension in 5 patients $(7 \%)$, chronic otitis media in 3 patients $(4.3 \%)$, chronic sinusitis in 2 patients (2.8\%), bronchial asthma in 2 patients $(2.8 \%)$.

According to the results of CSF culture, the patients were classified into two groups; aseptic meningitis group (A) included sixty-one patients $(87.1 \%)$ with negative CSF bacterial culture, and bacterial meningitis group (B) included nine patients (12.9\%) with positive CSF bacterial culture and the most common infectious agent in the positive culture cases was Neisseria meningitides (7.1\%) (Figure 2.).

The majority of diagnosed cases were males $(57.1 \%)$ aged mostly less than ten years or more than 40 years. The death rate was $11.4 \%$ and $75.8 \%$ of cases completely improved (Table 2). Furthermore, table.2 illustrates the comparison of various characteristics and patient parameters between aseptic meningitis and bacterial meningitis patients (group A and group B), it showed that aseptic meningitis occurred more in young children, while, bacterial meningitis occurred equally in both young children and old adults. CSF analysis of the studied cases showed that the turbid high tension CSF was significantly prevalent in culture positive cases (66.7\%), while a clear high tension CSF was significantly prevalent in culture-negative cases $(37 \%)$. The median admission days was significantly higher in group B (12 days) compared to group A (9 days). All bacterial meningitis cases (group B) had no history of antibiotic use before admission; on the contrary, almost all cases of aseptic meningitis (58 cases) had a significant positive history of antibiotic use (Table 2). The blood total leukocyte count (TLC) of the studied patients ranged from $1.5\left(\mathrm{x} 10^{3}\right.$ cells/ul $)$ to 27.5 $\left(\mathrm{x} 10^{3}\right.$ cells $\left./ \mathrm{ul}\right)$ with median $13\left(\mathrm{x} 10^{3}\right.$ cells $\left./ \mathrm{ul}\right)$ (Table 3).

Table (4) showed that significant predictors of mortality in our study were chronic diseases, age over fifty years old, coma, and low CSF glucose 
level. Among 15 patients who underwent a head CT scan prior to the LP, three cases had abnormal CT scan suggestive for raised intracranial pressure and were transferred for further neurosurgery evaluation in Zagazig University Hospital.

Table (1) : Demographic data of the studied cases (total $=70$ )

\begin{tabular}{|l|c|}
\hline Age (years) & $26.5(28 \pm 21.5)$ \\
Median, (mean \pm SD) & $47(67.1)$ \\
Residence & $23(32.9)$ \\
Urban & $24(34.3)$ \\
Rural & $6(8.6)$ \\
\hline Seasonal distribution of cases & $30(42.9)$ \\
Summer & $10(14.2)$ \\
Autumn & \\
Winter & \\
Spring & \\
\hline
\end{tabular}

All values are expressed as number (percentage);unless otherwise stated. $\mathrm{SD}=$ standard deviation.

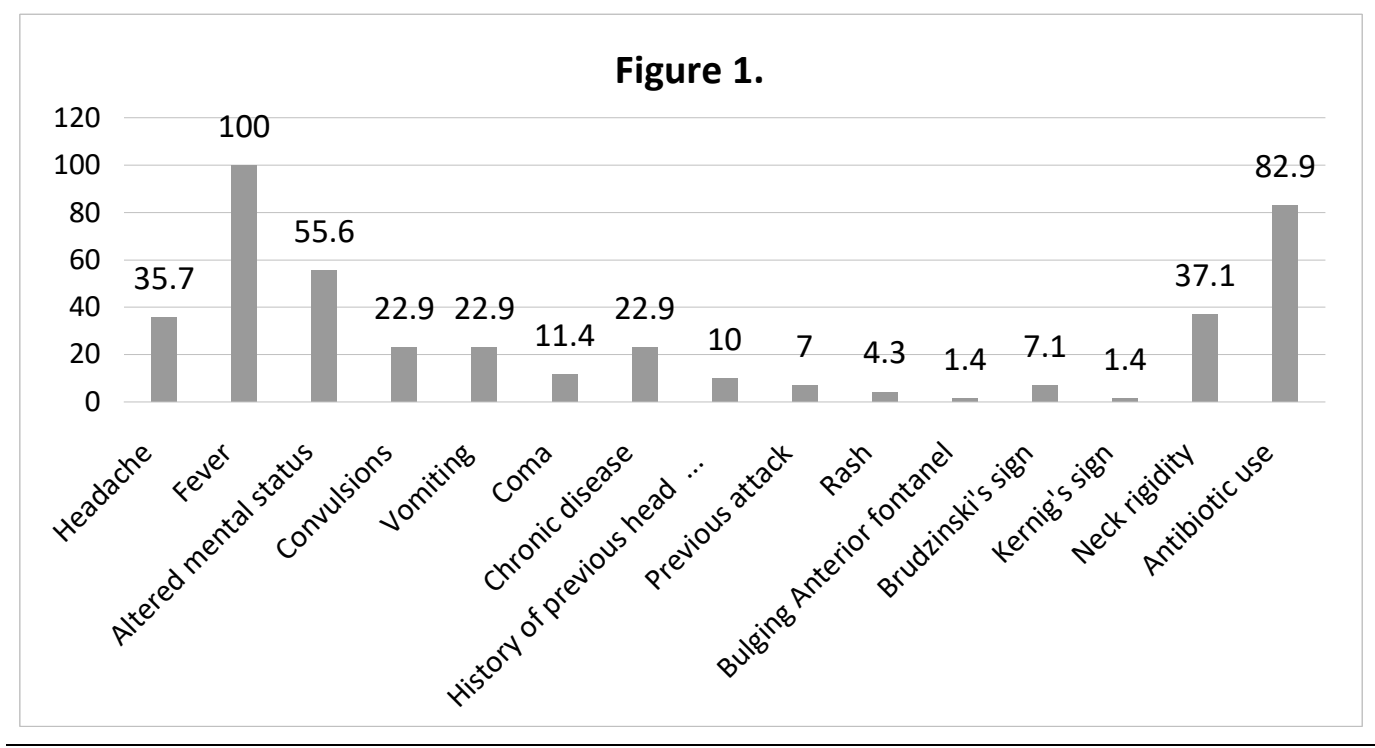

Figure (1) : Clinical symptoms and signs among ZFH meningitis cases 


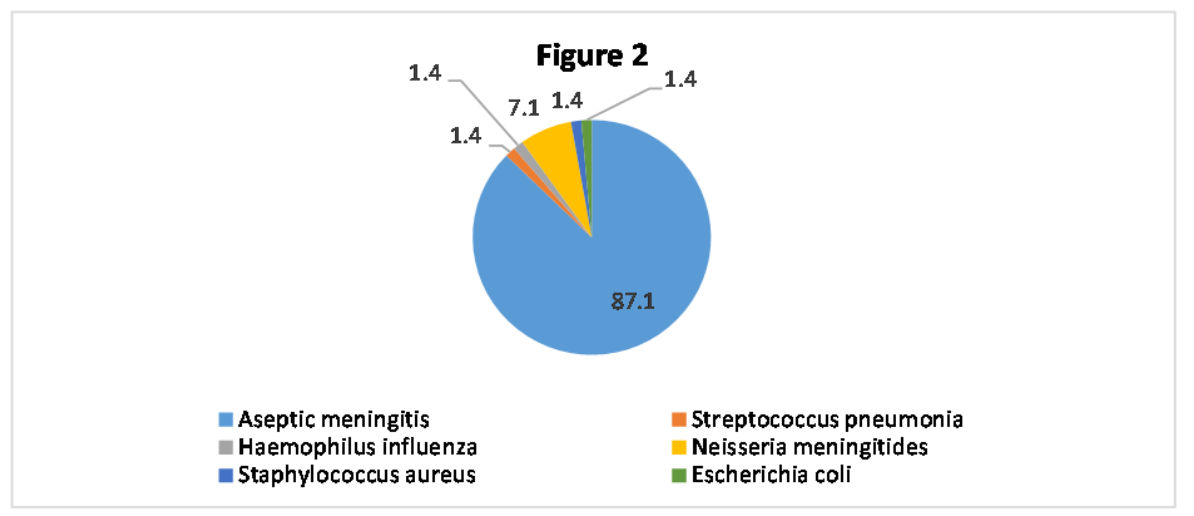

Figure (2) : Percentage of CSF culture findings among ZFH meningitis

Table (2) : Comparisons of the characteristics between culture negative and positive patients

\begin{tabular}{|c|c|c|c|c|c|c|}
\hline Parameters & Total $(n=70)$ & $\begin{array}{c}\text { Aseptic } \\
\text { meningitis } \\
(\mathbf{n}=\mathbf{6 1}) \\
\end{array}$ & $\begin{array}{c}\text { Bacterial } \\
\text { meningitis } \\
(\mathbf{n}=9) \\
\end{array}$ & $x^{2}$ & $\begin{array}{c}\text { P- } \\
\text { Value }\end{array}$ & \\
\hline $\begin{array}{l}\text { Age (years); } \\
<10 \\
10-<25 \\
25-40 \\
>40\end{array}$ & $\begin{array}{ll}23 & (32.9) \\
14 & (20.0) \\
13 & (18.6) \\
20 & (28.6) \\
\end{array}$ & $\begin{array}{l}20(32.8) \\
13(21.3) \\
11(18.0) \\
17(27.9) \\
\end{array}$ & $\begin{array}{l}3(33.3) \\
1(11.1) \\
2(22.2) \\
3(33.3) \\
\end{array}$ & $\begin{array}{l}0.01 \\
0.07 \\
0.09 \\
0.12 \\
\end{array}$ & $\begin{array}{l}0.97 \\
0.79 \\
0.78 \\
0.73 \\
\end{array}$ & \\
\hline $\begin{array}{l}\text { Gender; } \\
\text { Male } \\
\text { Female }\end{array}$ & $\begin{array}{ll}40 & (57.1) \\
30 & (42.9) \\
\end{array}$ & $\begin{array}{l}32(52.5) \\
29(47.5)\end{array}$ & $\begin{array}{l}8(88.9) \\
1(11.1)\end{array}$ & 1.46 & 0.69 & ${ }^{\dagger \dagger} \mathrm{r} 2.56$ \\
\hline $\begin{array}{l}\text { Clinical signs ; } \\
\text { Brudzinski's sign } \\
\text { Kernig's sign } \\
\text { Bulging anterior fontanel } \\
\text { Multiple signs }\end{array}$ & $\begin{array}{ll}5 & (7.1) \\
1 & (1.4) \\
1 & (1.4) \\
26 & (37.1)\end{array}$ & $\begin{array}{ll}4 & (6.6) \\
1 & (1.6) \\
1 & (1.6) \\
20 & (32.8)\end{array}$ & $\begin{array}{l}1(11.1) \\
0(0.0) \\
0(0.0) \\
6(66.7)\end{array}$ & 0.66 & 0.72 & \\
\hline $\begin{array}{l}\text { CSF analysis } \\
\text { Clear normal tension } \\
\text { Bloody } \\
\text { Turbid high tension } \\
\text { Clear high tension } \\
\text { Semi turbid } \\
\text { Turbid normal tension }\end{array}$ & $\begin{array}{ll}6 & (8.5) \\
2 & (2.9) \\
19 & (27.1) \\
25 & (35.7) \\
14 & (20) \\
4 & (5.7)\end{array}$ & $\begin{array}{ll}6 & (9.8) \\
2 & (2.3) \\
13 & (21.3) \\
23 & (37) \\
13 & (21.3) \\
3 & (4.9)\end{array}$ & $\begin{array}{l}0(0.0) \\
0(0.0) \\
6(66.7) \\
1(11.1) \\
1(11.1) \\
1(11.1) \\
\end{array}$ & $\begin{array}{l}0.12 \\
0.03 \\
6.02 \\
9.50 \\
0.07 \\
0.09\end{array}$ & $\begin{array}{l}0.73 \\
0.98 \\
0.01 * \\
0.00^{*} \\
0.76 \\
0.74\end{array}$ & \\
\hline $\begin{array}{l}\text { CSF findings (median, range); } \\
\text { Total WBC count } \\
\text { PMN \% } \\
\text { Lymphocytes \% } \\
\text { Glucose } \\
\text { Protein }\end{array}$ & $\begin{array}{l}1000(10-7310) \\
74(5-95) \\
28(5-95) \\
48(3.1-150 \\
105(17-1392)\end{array}$ & $\begin{array}{l}100(10-2300) \\
70(5-95) \\
30(5-95) \\
50(3.1-150) \\
60(17-88)\end{array}$ & $\begin{array}{ll}1050 & (60-7310) \\
84 & (20-95) \\
10 & (5-80) \\
35 & (10-60) \\
255 & (32-1392) \\
\end{array}$ & & $\begin{array}{l}\dagger \dagger \\
0.00^{*} \\
0.03^{*} \\
0.04^{*} \\
0.03^{*} \\
0.00^{*}\end{array}$ & \\
\hline $\begin{array}{l}\text { Admission days, } \\
\text { median(range); }\end{array}$ & $10(3-22)$ & $9 \quad(3-22)$ & $12(3-22)$ & & $\begin{array}{l}+04 \\
0.04 *\end{array}$ & \\
\hline $\begin{array}{l}\text { Discharge condition; } \\
\text { Improved } \\
\text { Hypotonia \& Hyporeflexia } \\
\text { Death } \\
\text { Other sequelae }\end{array}$ & $\begin{array}{ll}53 & (75.8) \\
5 & (7.1) \\
8 & (11.4) \\
4 & (5.7) \\
\end{array}$ & $\begin{array}{ll}46 & (75.4) \\
4 & (6.6) \\
7 & (11.5) \\
4 & (6.6) \\
\end{array}$ & $\begin{array}{ll}7 & (77.8) \\
1 & (11.1) \\
1 & (11.1) \\
0 & (0.0) \\
\end{array}$ & 1.46 & 0.69 & \\
\hline $\begin{array}{l}\text { Clinical picture of cases; } \\
\text { Coma } \\
\text { Antibiotic use } \\
\text { Chronic Disease }\end{array}$ & $\begin{array}{ll}8 & (11.4) \\
58 & (82.9) \\
16 & (22.9)\end{array}$ & $\begin{array}{ll}6 & (9.8) \\
58 & (95.1) \\
11 & (18.0)\end{array}$ & $\begin{array}{ll}2 & (22.2) \\
0 & (0.0) \\
5 & (55.6)\end{array}$ & $\begin{array}{l}8.34 \\
29.7 \\
6.26\end{array}$ & $\begin{array}{l}0.02^{*} \\
0.00^{*} \\
0.01^{*}\end{array}$ & $\begin{array}{l}\dagger \dagger \dagger \\
\text { OR } 23.4 \\
\text { OR } 5.7\end{array}$ \\
\hline
\end{tabular}

All values are expressed as number (percentage): unless otherwise stated. PMN (polymorphonucleocyte). Reference ranges for CSF constituents: Total WBC (white blood cell count) reference (0-3 cells/ul), Glucose reference (50-80 mg/dl). Protein reference $(15-45 \mathrm{mg} / \mathrm{dl})[24] .+\mathrm{x}^{2}=$ Chi-square test., $\dagger \dagger \mathrm{r}=$ Correlation coefficient, $\dagger \dagger \mathrm{P}$ of Mann-Whitney $\mathrm{u}$ test, $\dagger+\uparrow+\mathrm{OR}$ $=$ Odds ratio, $* \mathrm{P}<0.05$ is significant. $\mathrm{P}=$ Level of significance

Dawod et al., Afro-Egypt J Infect Endem Dis 2019; 5(2):158-166

https://aeji.journals.ekb.eg/

http://mis.zu.edu.eg/ajied/home.aspx 
Table (3) : Laboratory results of the studied patients (total=70)

\begin{tabular}{|l|l|c|c|c|}
\hline \multicolumn{2}{|l|}{} & Median & Minimum & Maximum \\
\hline CRP $(\mathrm{mg} / \mathrm{dl})$ & RBCs $\left(\times 10^{6} / \mathrm{ul}\right)$ & 40 & 2 & 140 \\
\hline \multirow{4}{*}{ CBC } & 4.6 & 3.0 & 6.2 \\
\cline { 2 - 5 } & Hemoglobin $(\mathrm{g} / \mathrm{dl})$ & 11 & 8.6 & 17 \\
\cline { 2 - 5 } & Total leukocyte count $\left(\times 10^{3}\right.$ cells/ ul) & 13 & 1.5 & 27.5 \\
\cline { 2 - 5 } & Platelet $\left(\times 10^{3} / \mathrm{ul}\right)$ & 260 & 43 & 650 \\
\cline { 2 - 5 } & Neutrophil $(\%)$ & 47 & 0 & 93 \\
\cline { 2 - 5 } & Lymphocyte $(\%)$ & 14 & 0 & 84 \\
\hline \multirow{5}{*}{ Electrolytes } & Serum sodium $(\mathrm{mmol} / \mathrm{l})$ & 138 & 120 & 160 \\
\cline { 2 - 5 } & Serum potassium $(\mathrm{mmol} / \mathrm{l})$ & 4.2 & 2.6 & 8.6 \\
\hline \multirow{3}{*}{ Kidney function tests } & Urea $(\mathrm{mg} / \mathrm{dl})$ & 26 & 10 & 189 \\
\cline { 2 - 5 } & Creatinine $(\mathrm{mg} / \mathrm{dl})$ & 0.7 & 0.3 & 8.8 \\
\hline Serum glucose $(\mathrm{mg} / \mathrm{dl})$ & 130 & 60 & 580 \\
\hline \multirow{3}{*}{ Liver function tests } & SGOT $(\mathrm{u} / \mathrm{l})$ & 30 & 12 & 860 \\
\cline { 2 - 5 } & SGPT (u/l) & 28 & 10 & 685 \\
\cline { 2 - 5 } & ALP $(\mathrm{u} / \mathrm{l})$ & 120 & 68 & 680 \\
\cline { 2 - 5 } & Total Bilirubin $(\mathrm{mg} / \mathrm{dl})$ & 0.6 & 0.3 & 6.8 \\
\cline { 2 - 5 } & Total protein $(\mathrm{g} / \mathrm{dl})$ & 6.9 & 3.9 & 8.7 \\
\cline { 2 - 5 } & Albumin $(\mathrm{g} / \mathrm{dl})$ & 3.6 & 2.7 & 4.6 \\
\hline
\end{tabular}

Table (4) : Predictors of mortality in meningitis case

\begin{tabular}{|c|c|c|c|c|}
\hline Predictors & $\begin{array}{c}\begin{array}{c}\text { Total number of } \\
\text { deaths }(8)\end{array} \\
\end{array}$ & $(\%)$ & Odd Ratio & P-value \\
\hline $\begin{array}{l}\text { Age : } \\
\text { Young age }<10 \text { years } \\
\text { Older adults }>50 \text { years } \\
\text { Adults } 10-50 \text { years }\end{array}$ & $\begin{array}{l}3 \\
5 \\
0\end{array}$ & $\begin{array}{c}(37.5) \\
(62.5) \\
(0.0)\end{array}$ & $\begin{array}{l}0.27 \\
6.11 \\
0.02\end{array}$ & $\begin{array}{l}0.12 \\
0.02^{*} \\
0.89\end{array}$ \\
\hline $\begin{array}{l}\text { Coma } \\
\text { Comatose } \\
\text { Non-comatose } \\
\end{array}$ & $\begin{array}{l}6 \\
2 \\
\end{array}$ & $\begin{array}{l}(75) \\
(25 .)\end{array}$ & $\begin{array}{l}9.00 \\
0.11 \\
\end{array}$ & $\begin{array}{c}0.04^{*} \\
0.47\end{array}$ \\
\hline $\begin{array}{c}\text { Chronic disease } \\
\text { Present } \\
\text { Absent } \\
\end{array}$ & $\begin{array}{l}5 \\
3 \\
\end{array}$ & $\begin{array}{l}(62.5) \\
(37.5) \\
\end{array}$ & $\begin{array}{l}10.4 \\
0.33 \\
\end{array}$ & $\begin{array}{c}0.01 * \\
0.09 \\
\end{array}$ \\
\hline $\begin{array}{l}\text { CRP } \\
\text { Positive } \\
\text { Negative } \\
\end{array}$ & $\begin{array}{l}5 \\
3\end{array}$ & $\begin{array}{l}(62.5) \\
(37.5)\end{array}$ & $\begin{array}{l}0.63 \\
0.59\end{array}$ & $\begin{array}{l}0.56 \\
0.63\end{array}$ \\
\hline $\begin{array}{c}\text { CSF protein } \\
\text { High } \\
\text { Low }\end{array}$ & $\begin{array}{l}5 \\
3\end{array}$ & $\begin{array}{l}(62.5) \\
(37.5)\end{array}$ & $\begin{array}{l}0.52 \\
0.44\end{array}$ & $\begin{array}{l}0.71 \\
0.89\end{array}$ \\
\hline $\begin{array}{c}\text { CSF glucose } \\
\text { High } \\
\text { Low }\end{array}$ & $\begin{array}{l}2 \\
6\end{array}$ & $\begin{array}{l}(25) \\
(75)\end{array}$ & $\begin{array}{c}0.24 \\
7.4\end{array}$ & $\begin{array}{l}0.10 \\
0.04 *\end{array}$ \\
\hline
\end{tabular}

$* \mathrm{P}<0.05$ is significant 


\section{DISCUSSION}

Meningitis is a potentially life threatening disease with substantial morbidity and mortality worldwide, while in many world regions, it represents even more significant problem especially developing countries [4] and an endemic disease in Egypt [2]. Therefore, this study aimed to determine the frequency and clinical presentations of the meningitis cases in ZFH (2016-2017) to put recommendations to assist in improving the preventive and management measurements for meningitis. There was a marked decline in the total number of meningitis cases admitted to the hospital (70 cases) when compared to those admitted in 2014 and $2013(110$ \& 135 respectively) which could be due to the starting of meningococcal vaccination in some kindergartens and primary schools.

The median age of the 70 cases was 26.5 years (mean age of $28 \pm 21.5$ ). The most common age group of meningitis cases was less than ten years, followed by age older than forty years. Franco-Parades et al. detected a similar result [25]; this could be attributed to the immature immune system, overcrowding in classrooms and living in dormitories [26]. However, Sáez-Llorens and McCracken found that meningitis occurs equally in both young children and adults [27]; this may be due to the different underlying predisposing factors.

In this work, cases were males more than females and from urban areas more than rural ones this may be due to the frequent contact, population density and the proximity of infective and susceptible people in an urban population, which in turn, promotes disease transmission [28]. The majority of diagnosed cases of meningitis $(42.9 \%)$ were in winter, especially in February, while, the minority of cases $(8.6 \%)$ were in autumn. Sultan and his colleagues detected a similar result; this may be due to the cooler temperature and low relative humidity [29].

In $\mathrm{ZFH}$, fever was a constant feature in all meningitis cases; followed by altered mental status $(55.6 \%)$, neck rigidity $(37.1 \%)$ and headache (35.7\%). Van de Beek et al. [30] stated that 95\% of the patients had two out of the previous clinical symptoms. Neisseria meningitidis was the most common cause of meningitis in our work $(55.6 \%$ of bacterial meningitis and $7.1 \%$ of all cases). Neisseria meningitidis is consistently reported to be one of the leading causes of bacterial meningitis in the Middle East and North
Africa [31], and for a long time, it was the most common cause of bacterial meningitis [32]. On the other side, Shaban and Siam study found that Streptococcus pneumonia was the most common cause [33], and Egyptian study (1998-2004) placed Neisseria meningitidis as the third cause of bacterial meningitis [14]. We can explain this difference by the fact that the age-specific incidence of meningococcal meningitis is highest in young children [28,34], the most common age group affected in this study. Furthermore, other studies involved multiple centers with large study population and different predisposing factors.

From all diagnosed cases, $11.4 \%$ of cases died, and old age was a significant risk factor for mortality. The patients aged 65 or older are the most likely age group to die of meningitis due to the low immunity [35]. Yossri et al. [36] and Thigpen et al. [11] reported a nearly equal death rate of $16.1 \%$ and $12.2 \%$ respectively. In addition, there was no statistically significant difference in death rate and outcomes between aseptic meningitis group and bacterial meningitis group, this result was inconsistent with what reported by Van de Beek et al. [30] that viral meningitis has a better prognosis than bacterial meningitis. This may be due to most of our cases (82.9\%) received an antibiotic before admission which can reduce the ratio of positive culture by $20 \%$ [19] and results in increased negative cultures cases.

In our study, the meningitis patients with a positive history of antibiotic use before the diagnosis had a lower risk of death than those without a history of antibiotic use before the diagnosis, so we emphasize on starting antibiotic therapy in suspected cases even if the lumbar puncture cannot be done or head CT will be delayed [37]. The patients with no history of previous head trauma were more liable to die than those with a positive history, and this may be attributed to the low number of admitted cases with a history of previous head trauma (10\%). In addition, $75.8 \%$ of the patients improved, and $12.8 \%$ had residual morbidity, while, Rosenstein et al. reported that $20 \%$ of survivors of bacterial meningitis have permanent sequelae [12].

The $\mathrm{ZFH}$ is a major hospital in Al Sharkia governorate so; this sample can be a representative to the whole governorate. In addition, it is a period cross-sectional study, and not a record of base data, therefore, it is accurate data without missing cases.

Dawod et al., Afro-Egypt J Infect Endem Dis 2019; 5(2):158-166

https://aeji.journals.ekb.eg/

http://mis.zu.edu.eg/ajied/home.aspx 
Limitations: it was a single institution crosssectional study and thus may be unrepresentative of meningitis cases in the general population, and most cases had a history of antibiotic use (partially treated meningitis), which resulted in fewer positive results for CSF culture. Furthermore; unavailability of PCR in ZFH which can add value in the identification of the pathogen, particularly in patients with negative CSF culture and history of antibiotic use before admission.

\section{CONCLUSION:}

Meningitis is a real health problem in Al Sharkia governorate; Neisseria meningitis was the most common cause of septic meningitis. Health authorities in Sharkia governorate should focus their preventive efforts on the age group $<10$ years and then the age group $>40$ years. They should immunize all primary school and kindergarten children by meningococcal vaccine regularly every year before winter and overcome crowding in classrooms.

\section{RECOMMENDATION :}

Starting antibiotic therapy in suspected cases, even if the lumbar puncture cannot be done or head CT will be delayed, improves the meningitis cases prognosis. Further multi-center studies about the causes of epidemiological changes of the disease causative agents.

\section{Funding: None.}

Conflicts of interest: There are no conflicts of interest.

\section{REFERENCES}

1. Khater, WS \& Elabd, SH. Identification of Common Bacterial Pathogens Causing Meningitis in Culture-Negative Cerebrospinal Fluid Samples Using Real-Time Polymerase Chain Reaction. International Journal of Microbiology, 2016, 1-5. doi:10.1155/2016/4197187

2. Fouad, R, Khairy, M, Fathalah, W, Gad, T, El-Kholy, B \& Yosry, A. Role of Clinical Presentations and Routine CSF Analysis in the Rapid Diagnosis of Acute Bacterial Meningitis in Cases of Negative Gram Stained Smears. Journal of Tropical Medicine, 2014, 1-7. doi:10.1155/2014/213762

3. Control of epidemic meningococcal disease: WHO practical guidelines. (1998, January 01). Retrieved from http://apps.who.int/iris/handle/10665/64467
4. Brouwer, MC, Tunkel, AR \& Beek, DV. Epidemiology, Diagnosis, and Antimicrobial Treatment of Acute Bacterial Meningitis. Clinical Microbiology Reviews, 2010, 23(3), 467-492. doi:10.1128/cmr.00070-09

5. Biaukula, VL, Tikoduadua, L, Azzopardi, K, Seduadua, A, Temple, B, Richmond, P, Russell, FM. Meningitis in children in Fiji: Etiology, epidemiology, and neurological sequelae. International Journal of Infectious Diseases, 2012, 16 (4). doi:10.1016/j.ijid.2011.12.013

6. Namani, SA, Koci, RA, Qehaja-Buçaj, E, AjazajBerisha, L \& Mehmeti, M. The epidemiology of bacterial meningitis in Kosovo. The Journal of Infection in Developing Countries, 2014, 8(07) 823-830. doi:10.3855/jidc.3553

7. Van de Beek, D, de Gans JJ, Spanjaard, L, Weisfelt, M, Reitsma, JB \& Vermeulen, M. Clinical Features and Prognostic Factors in Adults with Bacterial Meningitis. New England Journal of Medicine, 2004, 351(18), 1849-1859. doi:10.1056/nejmoa040845

8. Mace, SE. Acute Bacterial Meningitis. Emergency Medicine Clinics of North America, 2008, 26(2), 281-317. doi:10.1016/j.emc.2008.02.002

9. Scarborough, $M \&$ Thwaites, GE. The diagnosis and management of acute bacterial meningitis in resource-poor settings. The Lancet Neurology, 2008,7(7), 637-648. doi:10.1016/s1474-4422 (08) 70139-x

10. Global, regional, and national age-sex specific all-cause and cause-specific mortality for 240 causes of death, 1990-2013: A systematic analysis for the Global Burden of Disease Study 2013. (2015). The Lancet, 385(9963), 117-171. doi:10.1016/s0140-6736(14)61682-2

11. Thigpen, MC, Whitney, CG, Messonnier, NE, Zell, ER, Lynfield, R, Hadler, JL, Schuchat, A. Bacterial Meningitis in the United States, 19982007. New England Journal of Medicine, 2011, 364(21), 2016-2025. doi:10.1056/nejmoa1005384

12. Rosenstein, NE, Perkins, BA, Stephens, DS, Popovic, $\mathrm{T} \&$ Hughes, JM. Meningococcal Disease. New England Journal of Medicine, 2001, 344(18), 1378-1388. doi:10.1056/nejm200105033441807. 2001;344:1378-1388

13. Abdelkader, MM, Aboshanab, KM, El-Ashry, MA \& Aboulwafa, MM. Prevalence of MDR pathogens of bacterial meningitis in Egypt and new synergistic antibiotic combinations. Plos One, 2017, 12(2). doi:10.1371/journal.pone.0171349

14. Afifi S, Wasfy MO, Azab MA, Youssef FG, Pimentel G, Graham TW, Mahoney F. Laboratory-based surveillance of patients with bacterial meningitis in Egypt (1998-2004). European Journal of Clinical Microbiology \& Infectious Diseases, 2007, 26(5), 331-340. doi:10.1007/s10096-0070280-x 
15. Global Emerging Infections Surveillance. (2000). Retrieved fromhttps://health.mil/Military-HealthTopics/Combat-Support/Armed-Forces-HealthSurveillance-Branch/Global-EmergingInfections-Surveillance-andResponse?page=2\#pagingAnchor

16. Tunkel AR, Hartman BJ, Kaplan SL, Kaufman, BA, Roos KL, Scheld WM \& Whitley RJ. Practice Guidelines for the Management of Bacterial Meningitis. Clinical Infectious Diseases, 2004, 39(9), 1267-1284. doi:10.1086/425368

17. Hoffman $O$ and Weber JR. Review: Pathophysiology and treatment of bacterial meningitis. Therapeutic Advances in Neurological Disorders, 2009. 2(6), 401-412. doi:10.1177/1756285609337975

18. Ginsberg, L. Difficult and Recurrent Meningitis. Journal of Neurology, Neurosurgery \& Psychiatry, 2004, 75(90001), 16i-21. doi:10.1136/jnnp.2003. 034272

19. Lee, BE \& Davies HD. Aseptic meningitis. Current Opinion in Infectious Diseases, 2007, 20(3), 272-277. doi:10.1097/qco.0b013e3280ad4672

20. Sharqia Governorate. (2019, April 14). Retrieved from https://en.wikipedia.org/wiki/Sharqia_ Governorate

21. Hasbun, R, Abrahams, J, Jekel, J, \& Quagliarello, VJ. Computed Tomography of the Head before Lumbar Puncture in Adults with Suspected Meningitis. New England Journal of Medicine, 2001, 345(24), 1727-1733. doi:10.1056/nejmoa 010399

22. Gopal AK, Whitehouse JD, Simel, DL \& Corey, GR. Cranial Computed Tomography before Lumbar Puncture. Archives of Internal Medicine, 1999, 159 (22), 2681. doi:10.1001/archinte.159.22.2681

23. Joffe, AR.. Lumbar Puncture and Brain Herniation in Acute Bacterial Meningitis: A Review. Journal of Intensive Care Medicine, 2007, 22(4), 194207. doi:10.1177/0885066607299516

24. Kaplan, Pesce. Clinical Chemistry. Theory, Analysis, Correlation. 5th ed. St. Louis, MI: Elsevier Inc; 2010, 904-928.

25. Franco-Paredes, C, Lammoglia, L, Hernández, I, \& Santos-Preciado, JI. Epidemiology and outcomes of bacterial meningitis in Mexican children: 10year experience (1993-2003). International Journal of Infectious Diseases, 2008, 12 (4), 380-386. doi:10.1016/j.ijid.2007.09.012.

26. Genco, C; Wetzler, L, eds. Neisseria: Molecular Mechanisms of Pathogenesis. Caister Academic, 2010, ISBN 978-1-904455-51-6.

27. Sáez-Llorens, X, \& Mccracken, GH. Bacterial meningitis in children. The Lancet, 2003, 361(9375), 2139-2148. doi:10.1016/s0140-6736(03)13693-8
CDC. Centers for Disease Control and Prevention: (2014).

28. Olowokure, B, Onions, H, Patel, D, Hooson, J, \& Oneill, P. Geographic and socioeconomic variation in meningococcal disease: A rural/urban comparison. Journal of Infection, 2006, 52(1), 61-66. doi:10.1016/j.jinf.2005.01.013

29. Sultan, B, Labadi, K, Guégan, J, \& Janicot, S. Climate Drives the Meningitis Epidemics Onset in West Africa. PLoS Medicine, 2005, 2 (1). doi:10.1371/journal.pmed.0020006.

30. Van de Beek D, de Gans J, Tunkel AR, Wijdicks EF. Community-acquired bacterial meningitis in adults. The New England Journal of Medicine, 2006, 354 (1): 44-53. doi : 10.1056/NEJMra052116. PMID 16394301

31. Ceyhan M., Anis S, Htun-Myint L, Pawinski R, Soriano-Gabarró, M., \& Vyse, A. Meningococcal disease in the Middle East and North Africa: An important public health consideration that requires further attention. International Journal of Infectious Diseases, 2012, 16(8). doi:10.1016/j.ijid.2012.03.011

32. Girgis NI, Sultan Y, Erian MW, Sippel JE, Cross, E, Mikhail IA, Kilpatrick ME. Meningitis and Encephalitis at the Abbassia Fever Hospital, Cairo, Egypt, from 1966 to 1989. The American Journal of Tropical Medicine and Hygiene, 1993, 48(1), 97-107. doi:10.4269/ajtmh.1993.48.97

33. Shaban, L, \& Siam, R. Prevalence and antimicrobial resistance pattern of bacterial meningitis in Egypt. Annals of Clinical Microbiology and Antimicrobials, 2009, 8 (1), 26. doi:10.1186/ 1476-0711-8-26

34. Bosis S, Mayer, A \& Esposito S. Meningococcal disease in childhood: epidemiology, clinical features and prevention. Journal of Preventive Medicine and Hygiene, 2015, 56 (3), E121-E124. CDC. Centers for Disease Control and Prevention: (2012).

35. Domingo, P., Pomar, V., de Benito, N., \& Coll, $\mathrm{P}$. The spectrum of acute bacterial meningitis in elderly patients. BMC Infectious Diseases, 2013, 13, 108. doi:10.1186/1471-2334-13-108

36. Yosry A, Gad, T, Fathalah, W, Khairy, M, Hafez, HA \& Fouad, R. (2014). Epidemiological profile of patients suspected with meningitis: A crosssectional study among 1712 Egyptian patients.

37. Proulx N, Frechette D, Toye B, Chan J \& Kravcik S. Delays in the administration of antibiotics are associated with mortality from adult acute bacterial meningitis. Qjm, 2005, 98(4), 291-298. doi:10.1093/qjmed/hci047 